\title{
G-Ratio in hardened steel grinding with different coolants
}

Martin Novak, Roman Dolezal

Faculty of Production Technology and Management, J. E. Purkyně University in Usti nad Labem. Na Okraji 1001,400 01 Usti nad Labem. Czech Republic. E-mail: novak@fvtm.ujep.cz.

This article deals with grinding of the hardened and tempered steel in different coolants. The G-ratio is one of the important parameters of grinding process and shows efficiency of this. The development of machining technologies is still moving forward, there are new materials and types of tool using in production and manufacturing. With a new materials usage we want better parameters of process, e. g. higher G-ratio, lower heat balance and better surface quality after machining. New types of abrasive grains that we used are based on $\mathrm{Al}_{2} \mathrm{O}_{3}-$ microcrystalline corundum and parameter of G-ratio and surface quality after grinding will be described in this article. For experiment were chosen three types of coolants and one of grinding wheel. We can see changes of $G-$ ratio and surface quality during grinding at different coolants.

Keywords: Grinding, G-ratio, Microcrystalline corundum, Wear

\section{Acknowledgement}

Above mentioned results were created by means of national project GA CR No. 101/09/0504, project Postdoc in J. E. Purkyne University in Usti nad Labem.

CZ.1.07/2.3.00/30.0028

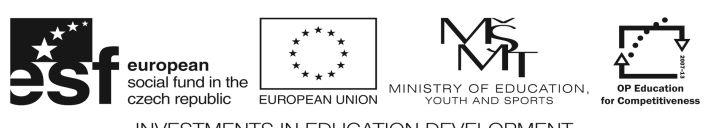

INVESTMENTS IN EDUCATION DEVELOPMENT

\section{References}

[1] HOLESOVSKY, F., NOVAK, M. (2009). Influence of grinding on machine parts with desing notches. In: Manufacturing Technology, vol. 9, no. 9., UJEP, Usti n. Labem, 40-46 pp.

[2] HOLESOVSKY, F., NAPRSTKOVA, N., NOVAK, M. (2012). GICS for grinding process optimization. In: Manufacturing Technology, vol. 12., no. 12., UJEP, Usti nad Labem, 22-26 pp.

[3] JERSÁK, J. (2012). Vliv dynamickeho vyvazeni brousiciho kotouce na drsnost povrchu obrobenych soucasti. In: Strojirenska technologie, vol. XVII., no. 1, 2., UJEP, Usti nad Labem, 27-33 pp.

[4] KOCMAN, K. (2012) Optimalizace dokoncovacich operaci vyrobnich procesu. In: Strojirenska technologie, vol. XVII., no. 1, 2., UJEP, Usti nad Labem, 164-169 pp.

[5] KUNDRAK, J. (2011). Alternative machining procedures of hardened steels. In Manufacturing Technology, vol. XI., no. 11., UJEP, Usti nad Labem, 32-39 pp.

[6] LUKOVICS, I., BILEK, O., HOLEMY, S. (2010). Development of Grinding Wheels for Tools Manufacturing. In: Manufacturing Technology, vol. 10., no. 10., UJEP, Usti nad Labem, 10-16 pp.

[7] MARINESCU, I., D., et all. (2007). Handbook of Machining with Grinding wheels. Boca Raton: CRC Press. $592 \mathrm{pp}$.

[8] MALKIN, S. (1989). Grinding Technology: Theory and applications of machining with abrasives. SME. $275 \mathrm{pp}$.

[9] MULlER, M., VALASEK, P. (2012). Abrasive wear effect on Polyethylene, Polyamide 6 and polymeric particle composites. In Manufacturing Technology, vol. 12., no. 12., UJEP, Usti nad Labem, 55-59 pp.

[10] NOVAK M., LATTNER M., RUZICKA L., HOLESOVSKY F., (2010). Grinding and surface quality parameters at automotive parts machining. In Manufacturing Technology, vol. 10., no. 10., UJEP, Usti nad Labem, 36$38 \mathrm{pp}$.

[11] NOVAK, M. (2012). Influence of the Corrosion Surrounding on Surface Quality of Ground Hardened Steels In Key Engineerings Materials, vol. 496: Precision Machining IV. TTP. Zurich. $25 \quad-\quad 30$ pp. WOS:000302674400005.

[12] NOVAK, M. (2011). Surface quality of hardened steels after grinding. In: Manufacturing Technology, vol. 11., no. 11., UJEP, Usti nad Labem, 55-59 pp. 
[13] NOVAK, M. (2012). Surfaces with high precision of roughness after grinding. In Manufacturing Technology, vol. 12., no. 12., UJEP, Usti nad Labem, 66-70 pp.

[14] NOVAK, M., NAPRSTKOVA, N., RUZICKA. L. (2012). New ways in aluminium alloys grinding. In Key Engineerings Materials, vol. 496: Precision Machining IV. TTP. Zurich. 132 - 137 pp. WOS:000302674400023.

[15] VASILKO, K., MACUROVA, A. (2012). Two local extremes of cutting speed. In Manufacturing Technology, vol. 12., no. 12., UJEP, Usti nad Labem, 86-89 pp.

[16] MULLER, M., VALASEK P. (2012). Abrasive wear effect on Polyethylene, Polyamide 6 and polymeric particle composites. In Manufacturing Technology. Vol. 12, No.: 12. UJEP, Usti n. Labem. pp. 55-59.

[17] KALINCOVA, D., BARBORAK, O., ANDREJCAK, I. (2011). Quality of chrome layers of coining dies and its impact on their reliability and lifetime in operation. In: Kovove materialy. Vol. 49, no. 6, pp 457-461. 